\title{
Transatlantica
}

Revue d'études américaines. American Studies Journal

1 | 2017

Morphing Bodies: Strategies of Embodiment in

Contemporary US Cultural Practices

\section{Doubleness on the New York Contemporary Experimental Stage: Bodies and Technology}

\section{Emeline Jouve}

\section{(2) OpenEdition}

\section{Journals}

Electronic version

URL: https://journals.openedition.org/transatlantica/9475

DOI: $10.4000 /$ transatlantica.9475

ISSN: $1765-2766$

\section{Publisher}

Association française d'Etudes Américaines (AFEA)

Electronic reference

Emeline Jouve, "Doubleness on the New York Contemporary Experimental Stage: Bodies and Technology", Transatlantica [Online], 1 | 2017, Online since 19 November 2018, connection on 20 May 2021. URL: http://journals.openedition.org/transatlantica/9475 ; DOl: https://doi.org/10.4000/ transatlantica.9475

This text was automatically generated on 20 May 2021.

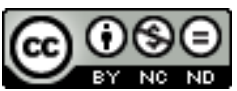

Transatlantica - Revue d'études américaines est mise à disposition selon les termes de la licence Creative Commons Attribution - Pas d'Utilisation Commerciale - Pas de Modification 4.0 International. 


\title{
Doubleness on the New York Contemporary Experimental Stage: Bodies and Technology
}

\author{
Emeline Jouve
}

\section{Introduction: Technology, Wonders and Worries}

\begin{abstract}
AH, TECHNOLOGY! The bogeyman that threatens to fetter our bodies to gadgets, entangle our synapses in wires, thieve our memories, erode our free will, etc. Popular stories remain riddled with the plagues and punishments that befall humanity when it believes it possesses the power to create the new, to exceed the limits of the body, to trump mortality. And in the end we always save ourselves somehow, don't we? (Krasinski 2015)
\end{abstract}

1 Technology both worries and fascinates. In her review of the 2015 COIL Festival, one of the "don't-miss" live performance events during the festival month of January in New York City, Jennifer Krasinski introduces technology as a symptom of our collective fear of losing human control in our contemporary hyper-mediatized society. As the latest edition of the highly representative COIL Festival shows, the experimental scene usesand abuses-new technologies. Although often denounced as socially oppressive, technology also serves as a means of artistic emancipation for the artists who explore the limits of the theatrical form and thus manage to "save" the human from the machine. The ambivalence between worry and fascination, alienation and emancipation as well as complacency and resistance may be characteristic of our "posthuman" condition, in which we often assume the interconnection between humans and digital technology. This new condition has been a great source of inspiration for experimental artists who have been playing with digital media to question their place in society. To study whether the human disappears under the weight of technology or if, on the contrary, its presence is magnified in contemporary experimental productions, this essay focuses on the theatricalization of the actors' bodies via the use of technology. 
"A new multiform kind of theatrical discourse" or what Hans-Thies Lehmann famously called "postdramatic theatre" (Lehmann 22) has developed since the 1960s. For the past decade, researchers have been exploring the field of digital aesthetics with great intensity. The titles of the numerous articles and books produced often assert the primacy of technology. This scholarly stand-in line with Philip Auslander's conclusions in Liveness: Performance in a Mediatized Culture-is representative of the process by which digital media has taken over the actors' and actresses' corporality on the experimental stage. ${ }^{1}$ In their final chapter of Multimedia Performance, Rosemary Klich and Edward Scheer conclude that the artistic exploration of "intermedial, even telematics performance" has displaced the body of the performer who is no longer viewed as the essence of theatre, the "foundation site of meaning in performance." For them, "as this body is being remediated, relocated and reframed, the corporeal dimension in multimedia theatre is being transferred from the body of the performer to the body of the spectator" (Klich \& Scheer 204). Such recurrent arguments have compelled me to question this withdrawal of the performer's presence in intermedial productions and to search for contemporary experimental shows that use technology but not at the expense of the corporality of the actors/actresses. I argue that the multimedia works by the pioneering Wooster Group (1975-), the eminent Big Art Group (1999-) and the new rising star of experimental theatre, Andrew Schneider (2015-) illustrate how some artists manage to renew traditional theatre thanks to digital media yet without disempowering the performer who remains a central figure.

3 To bring to light the creative interaction between technology and bodies in the shows of the groups and artists mentioned above, I draw from the concept of doubleness, which functions as a potent paradigm in the artists' approach to our post-modern condition. These artists use digital media to reflect on the duality of the human subject rather than to depict a homogenized world dominated by the machine. Each creator under scrutiny employs the aesthetics and definition of doubleness differently. The Wooster Group superimposes the physical body of the actor on its virtual video representation creating a Döppelganger effect and immersing the audience into the uncanny, while Big Art Group fragments the very bodies of the character-actors who appear as hybrid and monstrous, reminding us of Mikhail Bakhtin's theory of the carnivalesque. Andrew Schneider, on the other hand, doubles human bodies themselves through the use of technology and plunges us in a quantum universe in which the principle of the "reality D-fect" rules supreme.

\section{Wooster Group's Double Bodies: the Uncanny}

4 Wooster Group stages "double bodies" insofar as the physical, concrete bodies of the actors share the stage with their mirror-avatars. For David Z. Saltz in "A Taxonomy of Performer-Media Interactions," Elizabeth LeCompte's company often resorts to what he defines as "media as mirror, or" media which "reflec[t] the performer's action" (Saltz 104). Yet I would argue that this mirror held up to the character-performer offers a distorted vision of the body on stage to further blur the boundary between the familiar and the unfamiliar.

5 A recurrent feature in the company's shows, bodies-or fractions of bodies-are screened behind or above the actors embodying characters who are observed either by their video-Doppelgangers or by the spectators themselves turned into voyeurs. 
Through the use of video, technology dramatizes surveillance and desire, two elements at play in the "uncanny." The uncanny, Sigmund Freud wrote in his 1919 essay, "tends to coincide with whatever excites dread." It "leads back to something long known to us, once very familiar" (Freud 1). The feeling of unease thus arises from the tension between the familiar and the unfamiliar. The presence of physical actors is familiar to any theatre audience; theatre traditionally is about bodies moving about on stage. And yet the familiarity of the concrete bodily presence is challenged by the ghostly technological bodies screened on TV sets as they depart from traditional representations of bodies on stage. This effect of estrangement between the familiar and the unfamiliar was all the more powerful in the early years of Wooster Group since the company was one of the first to integrate video in its performances. Freud also claims that "the uncanny effect is often and easily produced by effacing the distinction between imagination and reality" (Freud 10): even though the theatrical world is one of fiction and illusion, the actors' bodies are "real" in the sense that they are "incarnated in the 'here and now' of the representation" while the bodies on screens remain virtual and represent the characters' angsts and fantasies, which are the products of their imaginations. As the pairs familiar-unfamiliar/reality-imagination illustrate, the uncanny relies on the notion of doubleness which is also symptomatic of the "disturbance of the ego," either "observing and criticizing the self" or, among other signs, experiencing forbidden desires (Freud 10). The analysis of the Wooster Group's doubling of bodies which follows centers on the staging of both surveillance and desire and is based on a limited yet representative corpus of productions In her 2016 volume Discipline and Desire. Surveillance Technologies in Performance, Elise Morrison studies the central dynamic at the core of that company's performances which, to some extent, prefigured the work of artists who used surveillance technology to critically reflect on the "Big Brother"-like system we live in. Interestingly, the book does not refer to Wooster Group, perhaps because Wooster Group rarely uses technology on stage to convey the oppressiveness of the media. Instead, it focuses on ways to theatricalize human duality.

6 Wooster Group presents both real bodies and technologized bodies to point to "false fixities." "The object body is exposed as having multiple meanings and is unable to be stably represented" (Parker-Starbuck106) - which can be interpreted in terms of surveillance. The characters on stage are often spied by virtual figures, technological Others representing an oppressive authority in the manner of the repressive double. The Döppelganger in Eugene's O'Neill's 1921 The Emperor Jones is that of Brutus Jones, performed by a black-faced white actress, Kate Valk. In this work, first produced in 1993 and revived in 2006, the company dramatizes the instability of gender and race, as well as issues of authorial and social authority. ${ }^{2}$ Brutus's double is his negative image, his "white" Döppelganger is Smithers, who not only represents white normative authority but also the authority of the all mighty creator, of the playwright, Eugene O'Neill. With his made-up moustache, the trader on stage looks like the author. ${ }^{3}$ Among other illustrations, one striking image is when Smithers's overexposed-and thus overwhite-face is screened on the TV set behind Brutus and next to Smithers himself, who turns his back to the fallen Emperor. The physical body of Smithers is doubled by his technological counterpart. The reiteration of the body of the white authority symbolizes Brutus's fatal entrapment by the white racist society of his creator. The overexposure turns Smithers into a ghostly uncanny figure, Brutus's racially oppressive shadow. Racial (over)exposure is a theme which Wooster Group has provocatively 
explored through both cosmetic and technological black-facing. ${ }^{4}$ In that sense, technology is used to dramatize surveillance under the guise of Big Brother, the whitemale normative gaze which alienates the individuals in spite of their emancipatory attempts.

In To You, the Birdie! (Phèdre), their 2002 adaptation of Racine's Phèdre, Wooster Group further explores the theme of surveillance by turning the spectators into accomplices in the act of spying on the protagonists' bodies. Throughout the play, inserts of the protagonists' bodies are screened on the TV set suggesting that reification is at play. The familiar bodies become unfamiliar, creating uneasiness. If the "screens also intervene as methods of surveillance and control, overseen by Venus" (Parker-Starbuck 119), they are also the lens through which the spectators have access to the most intimate parts of the protagonists' bodies:

At the start of To You, the Birdie! [...] Hippolytos (Ari Fliakos) and Theramenes (Scott Shepherd), enter the grid-like frame of the performance space and sit facing the audience downstage center, behind a large flat screen on which a pre-recorded projection of the lower halves of their bodies merges with the actions of their upper bodies. As the men begin to converse, setting up the plotlines of King Theseus lost at sea, Queen Phèdre's decline in health, Hippolytos's love for the forbidden Aricia, their eyes follow what suggests a badminton match in front of them. During this scene they causally fidget, reaching beneath the screen with arms that simultaneously appear on the screen below to adjust and scratch their genitals beneath the kilts they wear. The screen, shot slightly larger-than-life, creates a microscopic view that moves out-of-synch, slightly faster than the action of their physically present bodies. This visual technique is used throughout Birdie! suggesting a laboratory in which bodies are under scrutiny, observed and analyzed. (Parker-Starbuck 119-120)

8 By framing the bodies in this way, technology both fragments and reifies them into objects of desire. Venus and the spectators become voyeurs. The technological doubles, displaying the intimacy of the characters, represent the repressed desires of the characters but also of the spying audience. The staging of forbidden desires is thus another leitmotif of the works of the company. Their production of Tennessee Williams's Vieux Carré displaying graphic inserts of body parts and screening of porn foregrounded this leitmotif as its central theme. ${ }^{5}$ Interestingly, very few scholars have discussed this work so far.

In House/Lights (1998; 2005), the company juxtaposes two unlikely source texts: Olga's House of Shame, a 1964 B-movie by Joseph Mawra, and Dr. Faustus Lights the Lights (1938) by Gertrude Stein. The theme of the double is structurally conveyed here by the combination of the two sources. If desire is blatantly explicit in the soft porn movie reference, the body paradoxically resists eroticization by the screen image. The physical body of Kate Valk, playing Elaine and Faustus, appears sensual as she caresses her breasts while the technological double of her chest-which is that of a man and which is screened before her-appears alien, asexual, Christlike. In this show, the physical body is the source of attraction when the technological body is more likely to create repulsion and uneasiness. The uncanny created in Wooster Group's House/Lights relies on the dramatization of the discrepancy between, on the one hand, the theatrical -here and now-and, on the other hand, the cinematographic-there and thenconveyed by the use of video. The characters appear split between the physical body of the actor and the broadcast body of another human being, since the screen image is not shot live-a hybrid, composite protagonist comes to life. House/Lights evokes the 
category of "televisual theatre," a term coined by Matthew Causey in 2006 in Theatre and Performance in Digital Culture: From Simulation to Embeddedness: this mode stages "gaps" between performers and screen, between the action on stage and the broadcasted action. Following Christophe Baugh on this, we may conclude that "the technological signifier's interplay can supply the performance with a fragmentation of here and not here, there and not there, and now and not now" (Baugh 38).

The splitting of bodies in Wooster Group's productions partakes in the postmodern deconstruction of the subject who is no longer unified. The uncanny multiplication of subjectivities through the staging of the technological double creates a sense of uneasiness. Technology results in a state of defamiliarization, preventing the audience from identifying with the characters and inviting them to reflect instead about human duality and our voyeuristic desire for the Other.

\section{Big Art Group's Hybrid Bodies: the Carnivalesque}

11 In her chapter "Big Art Group's Body Politics" from Cyborg Theatre: Corporal/ Technological Intersections in Multimedia Performance, Jennifer Parker-Starbuck uses the concept of the uncanny to describe the work of Big Art Group: "the bodies on stage and screen produce a sense of the Uncanny for the audience, and certainly for actors whose interactions are as much about precise timing and camera choreography as the many characters they embody" (Parker-Starbuck 198). I'd like to suggest, however, that doubleness in the company's productions goes beyond the uncanny and the tension between surveillance and desire-which is characteristic of the Wooster Group's productions. Here, doubleness is suggestive of the creation of a new order. The norm is turned upside down in the medieval tradition of the carnivalesque.

Big Art Group stages composite doubles, art forms that are "hybrid[s] of films and theatre." Caden Manson and Jemma Nelson, who founded the company in 1999, have made hybridity their trademark as they make clear in the presentation of their work:

Big Art Group uses language and media to push formal boundaries of theatre, film and visual arts; it creates culturally transgressive works and innovative performances using original text, technology and experimental methods of communication. Big Art Group has produced 12 original works: CLEARCUT, catastrophe (1999), The Balladeer (2000), Shelf Life (2001), Flicker (2002), House of No More (2004), Dead Set (2006-Serial Project), The People (2007-Serial Project), The Sleep (2007), The Imitation (2008), SOS (2008), Cityrama (2010-Serial Project), Broke House (2012). In these pieces founder and director Caden Manson invented the integrated spectacle "Real-Time Film," a hybrid of film and theatre in which actors recombined formal ideas of performance through the use of simultaneous acting on stage and for live video using complex choreography, digital puppetry and live video framing. The company's works exists in the contemporary stream of postdramatic performance, wherein traditional narratives and established performer-audience relationships have been opened up to create possibilities of innovative discovery. The work blends high and low technology, marginal and mainstream culture, and blunt investigation to confront complex issues about contemporary experience. (Big Art Group, 2017).

13 Through the Real-Time Film which Big Art Group developed and perfected in Shelf Life, Flicker and House of No More-on which I will now focus-the company stages hybrid characters. The generic "blen[d]," doubleness, of Big Art Group's inscribes itself on the very bodies of the characters who are double in their very integrity. The actors perform 
actions that are simultaneously projected onto screens. The set is divided into two different spaces, referred to as "positive" and "negative" spaces. For Manson the positive space, which corresponds to the "video space" with the screens, is the place of "the actor onstage being caught by the video"; the negative space, the theatrical space serving as both shooting set or acting area and as backstage or dressing room, is "the actor on stage not being caught by the video, still onstage, but off scene" (qtd. in Gallagher-Ross 59). Big Art Group raises the curtain on the theatrical fabric-as postdramatic theatre usually does-and dramatizes the making of images through the juxtaposition of the positive and negative spaces:

The processes of both acting and filming are made visible to the spectators who see the actors moving about in the negative space. At the very beginning of the [Flicker, for instance], before the blackout, this negative space is visually acknowledged as the actors are seen entering the stage to get ready. The stage displays three mounted stationary cameras and three screens running the width of the stage. The actors take their places behind the screens; their legs and feet, shoulders and head remaining visible to the audience. Their images are captured by the cameras and projected onto the screens. Therefore the positive space is supposed to be the result of what happens behind the screen, which is the process. (Boitel and Jouve, 2015)

Despite the visibility of the "gaps" between the negative and positive spaces, and between the onstage and broadcast action on stage, Real-Time Films do not qualify as "televisual theatre" in Causey's definition of the practice. Indeed, "the technological signifier's interplay" does not "supply the performance with a fragmentation of here and not here, there and not there, and now and not now." Rather, both spaces, the stage and the screens, represent different perspectives of the "here and now" (Baugh 38), and the bodies on screen are the combination of the different performances taking place "here and now" on stage. The bodies seen on screen are hybrid, half-human, halftechnological. Big Art Group gives life to cyborgs and monsters:

[T]aken literally (as a visual or physical composite)-a body fixed in its co-mingling of parts, machine and flesh-the cyborg has been considered "monstrous" and is often a figure out of control, feared and feminized, appearing at times to quell anxieties about technologies and "others"; taken metaphorically [...] the cyborg is politically resistant, an idea, as Donna Haraway has famously proposed, of "transgressed boundaries, potent fusions, and dangerous possibilities which progressive people might explore as one part of needed political work." (ParkerStarbuck 1)

Hybridity is a source of regeneration, both artistic and social and thus political for Caden Manson and Emma Nelson, whose aim is to create new identities pushing away the frontiers of the "American avant-garde":

Real-Time Film for us was about construction in a way, whereas if you look at the American avant-garde before that, there was deconstruction. They were tearing apart this construct to look into political underlinings, but they had torn it apart so much there was nothing left. Ours is coming out from a queer space, and we were saying, "What are these new identities that can come out of what has been ripped apart?" So it happened because we came with a new proposal. The American avantgarde had one proposal, which was tearing things apart, and we had a new one, which was "we're making Frankenstein-we're making these new identities," and Flicker really does embody that. (qtd. in Jouve, 2017, 148)

While Elizabeth LeCompte and her team deconstruct the bodies which appear as split, the directors of Big Art Group are interested in constructing new bodies on stage. Fragmentation does not lead to duplication as in Wooster Group's productions but to 
composition, the emergence of a composite monstrous body on the screens. This shift from deconstruction to construction is a specificity of the carnivalesque. During carnival, according to Bakhtin, the individual "comes into contact with other bodies of varying age and social caste" (Bakhtin 92). New identities are created away from the norms. Big Art Group goes a step further since bodies not only "come into contact" but merge together regardless of age, social caste but also gender, as the co-founder of the company explain:

When a character in Real Time Film crosses the screen, it's flickering between male, female, trans, black, white, and Asian, and oftentimes it's vivisected, and put together, and you have this monstrous identity up there where you have a black arm on an Asian woman. (qtd. in Gallagher-Ross 63)

Hierarchies between social types are abolished, as is the hierarchy between the human and the technological: in the "Real Time Film" shows, we can say with Bakhtin that "the utopian ideal and the realistic merge[s] in this carnival experience, unique of its kind" (Bakhtin 10). This ideal, to return to Parker-Starbuck's definition of "cyborg," could be that of Donna Haraway: in her "A Cyborg Manifesto: Science, Technology, and Socialist-Feminism in the Late Twentieth Century," Haraway argues in favor of the abolition of categories between the human, the machine and the animal to foster a more progressive political discourse which would result in a less oppressive society.

More "constructivists"-as Manson and Nelson define their approach-than "deconstructivists," Big Art Group does not view technology as a source of oppression but instead explores its potential as a language that translates contemporary lives. Realizing that "old models [weren't] working for them," as Jemma Nelson explains, they sought "new solutions to the old models" and "that's how [they] arrived at working with new forms and new technologies" (qtd. in Jouve, 2017). As Stéphane Boitel and I argue in "Theatre/Video and the Crossing of Boundaries: Big Art Group's Flicker (2002-2005): Stitching the Eye/I," "Manson and Nelson do not denounce our contemporary society of visual consumption but hope to raise the postmodern Man's awareness about the way He relates to images" (Boitel and Jouve, 2015). "Post-epic" like the shows by Wooster Group, Big Art Group's Real Time Films raise the question of "where to look" for the spectators who can gaze at the hybrid bodies on screens or at the performance of the actors and the construction of their fictive doubles in the negative space. The spectator is thus a "spectator-supervisor," that is, a critical member of the audience who watches the play to decipher the "tricks and subterfuges" that trap the viewers into the world of fiction (Banu 13, my translation). But this postBrechtian spectator has to confront his/her own double, the spectator-voyeur who comes out to be "an Aristotelian spectator caught unawares by unexpected turns of events and unforeseen situations" (Banu 27, my translation). Indeed, if technology breaks the illusion it also paradoxically reinforces it in Big Art Group's shows, which is a real tour-de-force. Contrary to Wooster Group, the Döppelganger is not dramatized in Big Art Group's Real Time pieces but concerns the spectators themselves. As Boitel and I conclude:

By activating diverse levels of reality-meaning multiple states of disbelief-by stitching the different layers and expectations, by atomizing the audience's gaze, forcing each viewer to choose what to look at, what to ignore, by engaging him/her to cut and edit images on his/her own terms, and ultimately by redefining a genuinely new "private," "personal" Eye/I, Flicker triggers an appealing aesthetical and political bomb and invites-or forces-us to take an active responsibility in bringing into life our own monsters. (Boitel and Jouve, 2015, italics in the original). 


\section{Andrew Schneider's Body Double: the Reality D-fect}

When Wooster Group are interested in deconstructing the subject, Big Art Group claims reconstruction through hybridization, and Andrew Schneider deals with constructionthe construction of our human perception. The Human and their relation to their surroundings are at the centre of the work by Schneider, who uses technology to enhance reality. With his 2015 Obie-Awards show Youarenowhere, "Mr. Schneider"-as New York Times reviewer, Alexis Soloski, deferentially refers to the rising star of the experimental galaxy-stands as a demiurge who infuses life onto the stage and into the auditorium through technology: 6

Performances that rely this heavily on technology can often feel dead inside-too regulated and preprogrammed to ever seem truly live. This is not a show like that. Instead it continually finds new ways to challenge and engage its viewers, to surprise and mystify us [...] This is a show about presence, about immediacy, about the hitches and hiccups of life in the phenomenal universe. With his tech and his tricks and his intensified monologues, Mr. Schneider explores the continuities and differences in the world each of us perceives. "We exist in each other's realities," he says. "But not in the way that we think we do." How might the world look different from the stage? From elsewhere in the audience? From somewhere behind the curtain? (Soloski, 2015)

Like his predecessors, Schneider uses technology as a stage language but contrary to Wooster Group or Big Art Group, technology is not an alienating tool in the postBrechtian definition of the term, but rather a means to immerse the audience into reality not as it is but as we perceive it. As the polysemic title implies, YouAreNowhere/ YouAreNowHere is a work about the relativity of apprehending presence, the volatile nature of being "here and now." Inspired by quantum theory and the uncertainty principle, the piece resorts to what I define as "reality D-fect"-pronounced as "defect"-that is the relativity of reality. The term is based on the Barthian concept of "reality effect." For Roland Barthes, the "reality effect" results from the presence of details in a fiction which contribute to verisimilitude. The "reality D-fect," on the other hand, refers to the introduction of elements in the fiction that appear to give a distorted vision of reality when, in fact, what seems to be the illusion, the magic, is the reality. Schneider's approach to bodies on stage resembles that of the quantum physician insofar that the artist stages bodies as unsettled particles whose physical reality appears illusory. With the support of technology, Schneider offers the spectators a quantic multi-representation of time and space-which appear as times and spaces-instead of a traditional linear representation. This break from tradition gives the false impression of a defect-ive representation of reality when in fact this approach brings us closer to the essence of reality.

21 Schneider is a Tech Wizard. Initially trained in musical theatre, he went back to graduate school to undertake-and complete-a Masters Degree in Interactive Telecommunications. Schneider's education marks a new generation of self-trained media artists in contrast to the previous one who hired professionals or were initially dabbling in technology, like Big Art Group. ${ }^{7}$ Although Schneider worked with Wooster Group as "their video person"-as he calls himself-for seven years (2007-2014), videos are not the central staging ingredients of what he considered as his first show (qtd. in Jouve, 2016). If he does use videos to humorously illustrate the theory of probability, 
high-tech is mostly used for light and sound effects. ${ }^{8}$ Schneider, who not only wrote and directed his autobiographical show but also performed in it, created a software to preprogram all the tech cues which would prompt the performance of the actor. The actor thus performs according to tech cues to which he can have direct access on stage through an earset. Based on light and sound scores, the choreography conveys the impression that the performer both appears and disappears in front of bewildered spectators trying to make sense of the magic. In her review for Time Out. New York, Helen Shaw writes:

Schneider, shirtless, with his face powdered white, seems to have grafted his nervous system directly into the lights. He twitches, and great, absurd, room-filling splashes of color appear and disappear; lightning-quick blackouts play odd tricks, deranging our time-sense. Schneider himself moves and speaks so quickly he seems to be flickering back to us from the future, blessing someone before they sneeze, even showing us the ending of his piece long before the coup-de-theatre that will implement it. (Shaw, 2015)

Schneider makes the spectators' heads spin as he disappears, only to then reappear, being nowhere and now here. This interplay on presence and absence is a nod to quantum theory. Thanks to his high-tech programming at the origins of the reality Dfect, Schneider performs the reality of the "atomic illusion" of presence. As Josette Féral writes, it is the "alternation between presence and absence which creates the effect of presence" (my translation). ${ }^{9}$ The physical presence of Schneider is all the more striking as he is able to move his body out of the performing space in the flicker of an eye. The "presence effect" which translates as the "charisma" of the actor is directly linked to the swift disappearance of the body made possible by the technological apparatus.

The coup-de-theatre, to which Shaw refers, occurs halfway through the show when the curtain falls to reveal Schneider's double. Schneider and his mirror-image, performed by the talented Peter Musante, simultaneously and symmetrically dance to a pop soundtrack: Robyn's "Call Your Girlfriend." The choreographies are so perfectly performed that the spectators are initially trapped into believing that Schneider's image is reflected on a background mirror before the two men break the illusion by desynchronizing their dances. The synchronization, not only of their movements but also of their lines, which they pronounce at the same time, is also made possible thanks to the tech programming and the indications in their earphones. Technology does not only give the cues for the blocking of Schneider's solo but also of the "dynamic duo," as Musante, Schneider's "body double," is also on stage. The twist of the play with the falling of the curtain is kept secret for the audience to enjoy the coup-de-théatre. Peter Musante is never introduced as an actor on the bill, and is only acknowledged as one of the contributors to the creation. Peter is Schneider's shadow image. In Youarenowhere, the double illustrates the illusionary nature of perception. Schneider revives the Theatrum Mundi topos as the traditional metatheatrical symbol of the falling of the curtain shows. Quantum physicians have demonstrated the relativity of reality; Schneider represents bodily presence as the result of tricks of perception which technology enables to fake on stage.

The mirror-effect spreads beyond the performing space into the auditorium. As the spectators wonder if the performer is not here, in front of them, they also ask themselves whether they are also here watching a show or dreaming what they are 
seeing. Relativity is not only represented on stage: it is also constantly experimented by the members of the audience who have to face their own subjectivities.

\section{Conclusion: Acting Out Technology}

"In the end, we always save ourselves somehow." Jennifer Krasinski concludes her introduction to the 2015 COIL Festival with these words. Technology on stage is not a symptom of the loss of human control. On the contrary, technology on stage demonstrates the human ability to control the machine for Wooster Group, Big Art Group and Andrew Schneider. Technology serves the artists who explore human doubleness in contemporary society: Wooster Group introduces their spectators to an uncanny world peopled with split personalities who are objects of both desire and coercion; Big Art Group invites them to a carnival, a world turned upside-down where hybridity rules supreme and may be seen as the paradigm of the future; Andrew Schneider plays with the reality D-fect to portray the Self and His double as a representation of the subjectivity of "being."

In 1966, in his paper "On Filmstage," Robert Blossom wrote that "our presence as bodies beg[an] to be suspect" (Blossom 72). Half a century after this assertion, bodies seem to have regained their legitimacy on stage. The actor's ability to play around with technology in the various pieces discussed here shows the superiority of the Human over the Machine which magnifies, rather than annihilates, the presence of the performers. Instead of disappearing behind the technology, the bodies of the actors who are doubled by various strategies are put in the limelight. Their expressivity and agility are heightened as they interact with special effects and confront them to survive as "actors" who are human agents rather than passive objects, puppets trapped by machinery. Borrowing Jemma Nelson's words, we may therefore conclude that "the real technology, the performed technology, is the actor" (qtd. in Jouve, 2017).

\section{BIBLIOGRAPHY}

AUSLANDER, Philip. Liveness: Performance in a Mediatized Culture. New York: Routledge, 1999.

BAKHTIN, Mikhail. Rabelais and His World. 1984. Translated by Helene Iswolsky, Bloomington: University Press, 1992.

BANU, Georges. La Scène surveillée : Essai. Arles : Actes Sud, 2006.

BAUGH, Christopher. Theatre, Performance and Technology: The Development of Scenography in the Twentieth Century. Basingstoke: Palgrave MacMillan, 2005.

BIG ART GROUP. "History," bigartgroup.com/about/big-art-group/

BLOSSOM, Roberts. “On Filmstage.” TDR: The Drama Review, vol. 11, no. 1, 1966, p. 68-72.

BOITEL, Stéphane and Emeline JOUVE. “The Big Art Group's Flicker (2002): Stitching the Eye/I.” Liminalities: A Journal of Performance Studies, vol. 11, no. 2, 2015, liminalities.net/11-2/ 
CAUSEY, Matthew. Theatre and Performance in Digital Culture: From Simulation to Embeddedness. London : Routledge, 2006.

FERAL, Josette and Edwige PERROT. "De la présence aux effets de présence. Écarts et enjeux." Josette FERAL, editor, Pratiques performatives : Body Remix. Rennes: Presses universitaires de Rennes, 2012.

FREUD, Sigmund. The Uncanny. 1919. Translated by David McLintock, New York: Penguin Books, 2003.

GALLAGHER-ROSS, Jacob. “Image Eaters: Big Art Group Brings the Noise.” TDR: The Drama Review, vol. $54, \mathrm{n}^{\circ} 4,2010$, p. 54-80.

HAGEMANN, Simon. Penser les médias au théâtre : des avant-gardes historiques aux scènes contemporaines. Paris: l'Harmattan, 2013.

HARAWAY, Donna J. “A Cyborg Manifesto: Science, Technology, and Socialist-Feminism in the Late Twentieth Century." Craig HANKS, editor, Technology and Values: Essential Readings. Chichester: Wiley-Blackwell, 2010, p. 225-246.

JOUVE, Emeline. "Big Art Group: The Creation and Promotion of a Contemporary Language for the Stage." Anna WEINSTEIN, editor. Perform: Succeeding as a Creative Professional. New York: Focal Press, 2017, p/146-153.

---. “Gender and Race Trouble: The Emperor Jones by The Wooster Group." Revue ANGLES, 2015, angles.saesfrance.org/index.php ?id =209

---. “Interview with Andrew Schneider. New York Express (1)." Miranda, vol. 13, 2016, miranda.revues.org/9443

---. “Through the Looking Glass. The Wooster Group's The Emperor Jones (1993, 2006, 2009): Representation and Transgression." Revista de Estudios Norteamericanos, vol. 17, 2014, 55-74, institucional.us.es/revistas/estudios/17/art_4.pdf

KLICH, Rosemary and Edward SHEER. Multimedia Performance. New York: Palgrave Macmillan, 2012.

KRASINSKI, Jennifer. “Mortal COIL.” Artforum. January, 31 $1^{\text {st }} 2015$, artforum.com/slant/id =50017

LEHMANN, Hans-Thies, Postdramatic Theatre. Trans. Karen Jürs-Munby. New York: Routledge, 2006.

MONKS, Aoife. “'Genuine Negroes and Real Bloodhounds': Cross-Dressing, Eugene O'Neill, the Wooster Group, and the Emperor Jones." Modern Drama, vol. 48, no. 3, 2006, p. 540-564.

MORRISON, Elise. Discipline and Desire. Surveillance Technologies in Performance. Ann Arbor: University of Michigan Press, 2016.

PARKER-STARBUCK, Jennifer. Cyborg Theatre: Corporeal/Technological Intersections in Multimedia Performance. Houndmills: Palgrave Macmillan, 2011.

SALTZ, David Z., "Sharing the Stage with Media: A Taxonomy of Performer-Media Interactions." Sarah BAY-CHENG, Jennifer PARKER-STARBUCK and David Z. SALTZ, editors. Performance and Media: Taxonomies for a Changing Field. Ann Arbor: University of Michigan Press, 2015, p. 93-125.

SHAW, Helen. "Under the Radar, COIL and more: part 2." Time Out. New York, January, $14^{\text {th }} 2015$, timeout.com/newyork/blog/reviews-of-under-the-radar-coil-and-more-part-2-011415 
SOLOSKI, Alexis. "Sensory Overload is Part of the Script." New York Times, January, $14^{\text {th }} 2015$, nytimes.com/2015/01/15/arts/andrew-schneiders-youarenowhere-is-at-the-coil-festival.html? - $r=2$

\section{NOTES}

1. Philip Auslander is a leading authority in the field of performance and technology. In the conclusion of his 1999 book, Liveness: Performance in a Mediatized Culture, Auslander argues that "since the late 1940s, live theatre has become increasingly like television and other mediatized cultural forms." "To the extent," he insists, "that live performances now emulate mediatized representations, they have become second-hand recreations of themselves as refracted through mediatization" (Auslander, 1999, 183).

2. For analyses of the themes of gender/race and authority in Wooster Group's The Emperor Jones, confer Emeline Jouve's "Gender and Race Trouble: The Emperor Jones by The Wooster Group" and “Through the Looking Glass. The Wooster Group's The Emperor Jones (1993, 2006, 2009):

Representation and Transgression."

3. In this play, the Döppleganger is therefore double as the character of Smithers is both the mirror-image of Jones at the level of the plot and of the author at the metatheatrical level.

4. Route 1 \& 9 (The Last Act) is one of the company's most controversial explorations of racial exposure. The show "was a radical revisioning of Thornton Wilder's Our Town and was a mishmash of popular past performance styles, including blackface minstrelsy and pornography, the combining of which caused controversy, protest, and the rescinding of forty per cent of the Group's funding from the New York State Council" (Monks 561).

5. On their website, Wooster Group date their production of Vieux Carré from 2011 but productions were presented in Paris (at the Centre Pompidou) and in Strasbourg in 2009.

6. An early version of this essay was given at the conference "Staging American Bodies" that took place at the university of Nice-Sophia Antipolis in March 2016. By the time of the submission, Andrew Schneider had created another show, After, presented at the 2018 edition of Under the Radar in New York, which I have not been able to include in this study.

7. In an interview, the founders of Big Art Group explain that they originally did not work with tech people, and "so [they] had to learn how to use the tools that we wanted to use" (qtd. in Jouve, 2017, 149).

8. The videos stage a female avatar and a male avatar in different trains. Schneider interacts with the video in the manner of a lecture and wonders whether the two people have any chance to meet and fall in love. Schneider humorously intertwines his demonstration with references to Craigslist, a popular advertisements website on which people can post "romance" messages.

9. “C'est l'alternance des moments de présence et d'absence qui créerait ainsi l'effet de présence" (Féral and Perrot, 17). 


\section{ABSTRACTS}

"Doubleness on the New York Contemporary Experimental Stage: Bodies and Technology" explores the representations of bodies in a corpus of plays by New York artists from the "New American Avant-Garde." Intermediality, or the co-presence or superimposition of different artistic media, creates dual bodies: technological monsters that are half-human and half-video, grotesque minotaurs at once men and puppets. A "place for viewing," theatre, theatron, is turned by artists into a showcase displaying post-human bodies. To what extent does the use of technology annihilate or magnify the physical presence of the actor, the traditional soul and raison d'etre of the art of the theatre? To answer this question, this paper focuses on works by the pioneering Wooster Group (1975-), the eminent Big Art Group (1999-) and the new rising star of the New York experimental scene, Andrew Schneider (2015-). I develop the concept of doubleness in order to define the nature of the interactions between bodies and technology in the various shows of the artists.

"Doubleness on the New York Contemporary Experimental Stage: Bodies and Technology" s'intéresse à la représentation des corps dans un corpus de pièces par des artistes new-yorkais de la «nouvelle avant-garde américaine. » Le principe d'intermédialité créé par la co-présence ou encore la superposition de différents médias artistiques, fait naître des corps duaux : monstres technologiques mi-humains, mi-vidéos, minotaures grotesques à la fois hommes et marionnettes. Le «lieu d'où l'on voit, " le théâtre, theatron, devient un lieu de monstration de corps posthumains. Dans quelle mesure le recours à la technologie se fait au détriment ou au contraire à l'avantage de l'acteur dont la présence incarne l'essence même du théâtre ? Afin de répondre à cette question, l'article revient plus particulièrement sur le travail du Wooster Group (1975-), du Big Art Group (1999-) et du nouveau venu de la scène expérimentale newyorkaise, Andrew Schneider (2015-). Le concept de dualité sera développé pour rendre compte des interactions entre corps et technologie dans les différentes productions.

\section{INDEX}

Mots-clés: Big Art Group, corps, carnavalesque, doubles, émancipation, théâtre experimental, présence, Andrew Schneider, défaut de réalité, technologie, inquiétante étrangeté, Wooster Group

Keywords: Big Art Group, bodies, carnivalesque, doubles, emancipation, experimental theatre, presence, Andrew Schneider, reality D-fect, technology, uncanny, Wooster Group

\section{AUTHOR}

\section{EMELINE JOUVE}

Laboratoire CAS, Université Toulouse Jean Jaurès--Institut National Universitaire Champollion emeline.jouve@univ-jfc.fr 